\title{
Micronization and extrusion processing on the physicochemical properties of dietary fiber
}

\author{
Ana Betine Beutinger Bender ${ }^{*}$ iD Fernanda Rodrigues Goulart ${ }^{2}$ \\ Leila Picolli da Silva ${ }^{2}$ Neidi Garcia Penna ${ }^{1}$
}

'Departamento de Tecnologia e Ciência dos Alimentos, Universidade Federal de Santa Maria (UFSM), 97105-900, Santa Maria, RS, Brasil. E-mail: betinebender@hotmail.com. "Corresponding author. ${ }^{2}$ Departamento de Zootecnia, Universidade Federal de Santa Maria (UFSM), Santa Maria, RS, Brasil.

ABSTRACT: Dietary fiber plays an important physiological role, which is directly linked to its physicochemical properties, water-holding, oil-binding, and cation-exchange capacities. These properties can be altered by employing enzymatic, mechanical, and physical processes. Enzymatic and chemical processes require solvents and special conditions that make it unfeasible to use. Thus, the use of physical methods, such as micronization and extrusion, make promising options to change the physicochemical properties of dietary fiber. In this way, this review aimed to approach relevant information about the use of physical processes, specifically micronization and extrusion, for this purpose. Furthermore, conceptual aspects, such as definition, classification, and properties of dietary fiber and mainly characteristics about the micronization and extrusion processes, are reported. Micronization and extrusion are based on the decrease of the particle size to a micro scale and on the combination of high temperature, mechanical shearing and pressure, respectively. Applying these methods, modifications on the food matrix occurred by increasing the surface area and disruption of the glycosidic bonds. Consequently, there is a change in physicochemical properties of dietary fiber, which predict the physiological effect associated with dietary fiber consumption, such as decrease in blood cholesterol and glucose levels and improvement of intestinal transit. Moreover, these changes increase the bio accessibility of bioactive compounds present in the food matrix and improve the antioxidant capacity of products.

Key words: grinding, hydration properties, mechanical shearing, particle size, soluble dietary fiber.

Efeito dos processos de micronização e extrusão nas propriedades físico-químicas da fibra alimentar

RESUMO: A fibra alimentar desempenha importante papel fisiológico, o qual está diretamente ligado às suas propriedades físico-químicas de capacidade de retenção de água, ligação ao óleo e a cátions. Estas propriedades podem ser alteradas empregando-se métodos enzimáticos, químicos e físicos. Métodos enzimáticos e químicos requerem solventes e condições específicas que inviabilizam sua utilização. Assim, o emprego dos métodos físicos, tais como micronização e extrusão, tornam-se alternativas promissoras para alterar as propriedades fisicoquímicas da fibra alimentar. Desta forma, este trabalho visa abordar informações relevantes sobre o uso dos processos físicos, especificamente micronização e extrusão para essa finalidade. Além disso, aspectos conceituais como definição, classificação e propriedades da fibra alimentar e as principais características dos processos de micronização e extrusão são relatados. Micronização e extrusão baseiam-se na diminuição do tamanho de particula para microescala e na combinação de alta temperatura, pressão e força de cisalhamento, respectivamente. Aplicandose estes métodos, modificações na matriz alimentícia ocorrem pelo aumento da área superficial e rompimento das ligações glicosídicas da matriz alimentar. Consequentemente, são observadas alterações nas propriedades fisico-químicas da fibra alimentar, as quais predizem o efeito fisiológico associado ao seu consumo, como diminuição dos níveis de colesterol e glicose sanguíneos e a melhora do trânsito intestinal. Ademais, essas alterações aumentam a bioacessibilidade dos compostos bioativos presentes na matéria-prima alimentícia e melhoram a capacidade antioxidante dos produtos obtidos.

Palavras-chave: moagem, propriedades de hidratação, cisalhamento mecânico, tamanho de partícula, fibra alimentar solúvel.

\section{INTRODUCTION}

In the face of increasing demand from consumers for a healthy and balanced lifestyle, besides that the population eats deficiently in quantity and quality, it is important to include dietary fiber in the diet. This nutrient plays important roles in the body, such as interference in the metabolism of lipids and carbohydrates and in the physiology of the gastrointestinal tract, as well as ensuring slower absorption of nutrients and promoting a feeling of satiety.

Recent research has shown that a high fiber diet decreases the concentration of physiological markers associated with cardiovascular risk, such as total cholesterol, low density lipoprotein and triglycerides (CHEN et al., 2014). The effect is related 
to the physicochemical properties of dietary fiber, water-holding, oil-binding, and cation-exchange capacities. Besides the absorption of bile acids, which have significant roles in the prevention of diet-dependent diseases (obesity, atherosclerosis and colon cancer), as well as nitrite absorption capacity, which is related to the protection against gastric cancer (ZHU et al., 2015).

The most pronounced beneficial effects of dietary fiber are associated with its soluble fraction. However, in most of cases, insoluble fiber is reported in higher amounts in food matrices. Thus, this fraction can be converted into soluble fiber by physical methods, which modify the nutritional properties of the final product (HUANG \& MA, 2016). Changes in fiber structures, both internal and external, affect its physicochemical properties, through a larger surface and an internal area, and the activation of more water and oil molecules (YAN et al., 2015).

Micronization and extrusion processing are physical methods used to change the physicochemical properties of dietary fiber. Both processes could be considered not harmful to the environment due no residues generation, with great alternatives for this purpose. However, it is important to understand the processes for comprehending the changes that they occur. In this way, this review aimed to address the use of physical methods, micronzation and extrusion, as alternatives to improve the physicochemical properties of dietary fiber.

\section{Definition, classification and composition of dietary fiber}

Dietary fiber is defined as "edible part of plants or analogous to carbohydrates that are resistant to digestion and absorption in the small intestine, with complete or partial fermentation in the large intestine. Dietary fiber includes polysaccharides, oligosaccharides, lignin and associated substances to plants" (AACC, 2001), such as phenolic compounds (VITAGLIONE et al., 2008). They are abundant in vegetable products such as fruits, vegetables and grains (DENG et al., 2011).

Dietary fiber consists of carbohydrate polymers that make up the cell wall of vegetables, including cellulose, hemicellulose and pectins, as well as polysaccharides from plants or obtained from algae, like gums and mucilages and oligosaccharides, such as inulin. In addition, associated substances, mainly lignin and minor compounds (cutin, saponin and polyphenols) are included as components of dietary fiber (VITAGLIONE et al., 2008; MUDGIL \& BARAK, 2013).
Fibers are divided into two fractions, according to their solubility in water: insoluble fraction and soluble fraction. Insoluble fiber fraction is predominant in bran, leafy vegetables and grains and it consists mainly of insoluble cell wall components (cellulose, insoluble hemicelluloses and lignin) (ELLEUCH et al., 2011).

The physiological effect related to this fraction is associated with the decrease in intestinal transit time (DAI \& CHAU, 2017). Components of insoluble dietary fiber can increase fecal bulk by their water holding capacity that helping prevent and relieve constipation. By absorbing water, these components also absorb possible carcinogens, preventing colon cancer. However, they are minimally fermented by the intestinal microflora and; therefore, are poorly metabolized (MUDGIL \& BARAK, 2013).

The soluble fiber fraction consists of structural non-starch polysaccharides, such as $\beta$-glycans, arabinoxylans, pectins, some hemicelluloses; and also substances like gums and mucilages (ELLEUCH et al., 2011; MUDGIL \& BARAK, 2013). The physiological effect of this fraction is associated with delayed gastric emptying (greater satiety). Due their viscosity, soluble fibers form a superficial area along the small intestine, which slows digestion of nutrients by preventing bulk diffusion of foods across the intestinal lumen. Furthermore, the increased viscosity slows the absorption of glucose and lipids (KENDALL et al., 2010).

Unlike the insoluble fraction, the soluble fiber is selectively fermented in the large intestine by acidolytic bacteria, producing high concentrations of short chain fatty acids (SCFA), mainly acetate, propionate and butyrate. In the intestine, SCFAs function as protective agents for diseases like diarrhea, intestinal inflammation and colon cancer. Concomitantly, fermented fibers are converted into nutrients that stimulate growth and activity of beneficial bacteria, such as Bifidobacteria and Lactobacilli in the colon, increasing their levels (MUDGIL \& BARAK, 2013). Consequently, this condition improves host health (DAI \& CHAU, 2017).

In general, residues derived from processed fruits and vegetables contain high amounts of soluble dietary fiber and a better insoluble/soluble fiber ratio (HUANG \& MA, 2016). This fact is relevant because the relation is important for both, food and physicochemical properties. The soluble fraction, in comparison to the insoluble portion, presents a greater ability to form gels (YAN et al., 2015) and greater effectiveness in the maintenance of systemic 
health. The insoluble portion can be converted to soluble fiber by physical methods. So, changes in nutritional properties and texture of the product may occur (HUANG \& MA, 2016).

\section{Physicochemical properties of dietary fiber} The solubility of dietary fiber confers differences in functional and technological properties. Soluble fibers are characterized by the ability to increase viscosity, reduce glycemic response and plasma cholesterol (ABDUL-HAMID \& LUAN, 2000; KENDALL et al., 2010) as well as to demonstrate a better ability to form gels and/ or act as emulsifiers, compared to the insoluble fraction (ELLEUCH et al., 2011). Insoluble fibers are characterized by porosity, low density, ability to increase fecal bulk and decrease intestinal transit time that alleviating constipation and improving regularity (DAI \& CHAU, 2017). These physiological effects of dietary fiber depend mainly on their physicochemical properties, such as waterholding, oil-binding and cation-exchange capacities (MUDGIL \& BARAK, 2013).

Water-holding capacity is a measure used to evaluate the water absorption capacity of fibers. Its measurement is based on the amount of water that remains attached to hydrated fibers with the application of an external force (pressure or centrifugation) (DU et al., 2014). The hydration or water retention properties of dietary fiber are related to the chemical structure of the polysaccharides, besides the porosity, particle size, ionic form, $\mathrm{pH}$ and temperature. The fiber source is extremely related to the hydration capacity. Fibers from fruit by-products have higher affinity for water than residues from cereal processing. Such differences are related to the chemical properties of fibers (ELLEUCH et al., 2011).

Oil-binding capacity is defined as the amount of oil retained by fibers after mixing, incubation and centrifugation steps (ELLEUCH et al., 2011). This measure is influenced by the surface properties, as well as the density of the loads and hydrophobic nature of the constituents of dietary fiber. Increase in oil-binding capacity is directly related to the effects of cholesterol absorption. By attaching more effectively oil, the particulate material prevents or delays the absorption of blood cholesterol and thus decreases the circulating levels (CHAU et al., 2007).

According to water and oil-holding capacities, the use of fiber in food products is suggested. Dietary fibers with high oil-binding capacity can be used to stabilization of products with high lipid content and emulsions, such as sausages. However, dietary fibers with high hydration capacity can be used as functional ingredients to prevent syneresis and to modify viscosity and texture in food products such as jellies and breads (GRIGELMOMIGUEL et al., 1999; MUDGIL \& BARAK, 2013).

Cation-exchange capacity relates the ability of the fibrous matrix to bind ions and hold them on its surface. Thus, the reduction of the bioavailability of minerals and trace elements to the body from the gastrointestinal tract, is one of the key elements of dietary fiber consumption (DAOU \& ZHANG, 2012). As a result of the increase of cation-exchange capacity, a lipid emulsion destabilization occurs. Consequently, a reduction of lipid diffusion and absorption occurs, causing a decrease in blood triglyceride and cholesterol levels (CHAU et al., 2007).

Other in vitro analyzes to evaluate the physicochemical properties of dietary fibers include nitrite ion absorption capacity and glucose absorption capacity. Nitrite is a reactive ion and may react with amines or amides under acidic conditions and form nitrous compounds with human carcinogenic potential. The ability of nitrite removal may be a contributing factor in the possible role of high-fiber ingredients for protection against gastric cancer (DU et al., 2014).

The absorption capacity of glucose is related to the ability of dietary fiber to hinder diffusion of glucose and adsorb glucose by imprisoning it in the fibrous matrix. Because of this, there is a decrease in postprandial glucose concentration available for absorption in the intestinal lumen, and thus, may have hypoglycemic effects (CHAU et al., 2007).

\section{Methods for dietary fiber modification}

The physicochemical properties of dietary fiber can be modified with chemical, enzymatic, and physical methods. Chemical methods are based on acidic and/or basic hydrolysis for destruction of the cell wall. Hydrolysis of the cell wall polysaccharides may lead to an increase in soluble fiber content. Enzymatic treatment is also able to modify the relation between soluble and insoluble fiber, acting in specific binding sites of the fiber molecules; for example, application of xilanases for disruption of the cell wall, increases the soluble fiber content. However, it is known that enzymes act under optimum temperature conditions and a minimum incubation time is necessary (GUILLON \& CHAMP, 2000; ELLEUCH et al., 2011).

Therefore, the physical methods arise as an alternative for food processing that cause the 
region-chemistry change of the surface area, directly related to the physicochemical properties (absorption or binding of molecules), being responsible for some physiological effects of dietary fiber in the body (GUILLON \& CHAMP, 2000). Micronization and extrusion are examples of physical methods used to improve the functional properties of dietary fiber present in different food raw materials.

Micronization involves the reduction of particle size and is linked to changes in the surface area and functional properties of the ingredients tested. Extrusion involves heating in combination with homogenization, characteristics that also alter the functional properties of dietary fiber (DAOU \& ZHANG, 2012).

\section{Micronization or ultrafine grinding}

Micronization or ultrafine grinding is a physical process that reduces the size of dietary fiber particles for a given micro scale (size from $1 \mathrm{~nm}$ to $100 \mu \mathrm{m}$ ) (ZHANG et al., 2016), improving some of its physicochemical properties, such as waterholding and oil-binding capacity; solubility; ability of "cation-exchange" and adsorption of glucose; and the inhibitory activity of pancreatic lipase and $\alpha$-amylase (CHAU et al., 2007; DAOU \& ZHANG, 2012).

The use of ultrafine grinding technology presents great potential for use in nutraceutical and functional foods. By reducing the particle size; consequently, there is an increase in the surface area and, thus, the constituents of the ultra-fine particles are easily absorbed in the gastrointestinal tract by increasing the quality of the food products into which they are incorporated. In addition, the antioxidant components are maintained (DU et al., 2014).

Different techniques can be used to produce ultra-fine particles. One of the most traditional techniques makes use of the ball milling, which there is direct contact of the device with the material to be milled and the container is moved in three axial directions. Thus, the materials are sprayed and mixed by repeated high energy impacts. Friction of the starch and the water molecules against each other and against the balls and walls of the container produces heating that contributes to modify the properties of the starch granules and also of the other constituents of the food (dietary fiber and protein, for example) (WANG et al., 2009).

Another technique used is the jet milling, classified as a fluid energy impact milling technique, widely used for the production of ultra-fine powders. The jet mill is a static machine without milling media; the milling component consists of a chamber with a nozzle or nozzles and the particles to be sprayed are accelerated by the air pressure or steam jet. The effect of milling is produced by the collision between the particles or by impact against the solid surfaces of the equipment (DRAKOS et al., 2017).

\section{Extrusion}

Extrusion is commonly used in the preparation of snacks and breakfast cereals, assuming that it changes the chemical structure of food, especially starch products, since high temperatures facilitate the gelatinization of starch (AKDOGAN, 1997; SOUZA \& ANDRADE, 2000). Extrusion is a mechanical shear method involving the modification of the food matrix through association between temperature and pressure (DAOU \& ZHANG, 2012). The mechanical stress is capable of breaking the glycosidic bonds of the fibrous matrix, increasing the soluble fiber content, often used as a prebiotic (VITAGLIONE et al., 2008). This method is also useful for protein breakdown, being important because it increases the bioavailability of some amino acids, improving the nutritional quality of food sources (ASCHERI et al., 2006).

The mechanical treatment completely disorganizes the original structure of the material (DAOU \& ZHANG, 2012). During the extrusion, fiber solubilization may occur depending on the severity of the process (high temperature, high screw speed and low moisture content). Mechanical stress during the process may cause degradation of glycosidic bonds of the polysaccharides, leading to release of oligosaccharides and; consequently, the increase of the soluble fraction of fiber (VITAGLIONE et al., 2008).

Moreover, this mechanical modification has the ability to elevate the antioxidant capacity of the food, since this process breaks polyphenolic bonds associated to dietary fiber, increasing the bioaccessibility of the bioactive compounds present in raw material (MORALES et al., 2015). Since these compounds are sensitive to high temperatures, extrusion conditions (temperature, moisture, pressure, feed rate, screw speed) must be optimized for each array to be extruded (CHALERMCHAIWAT et al., 2015; LEVYACORRAL et al., 2016).

It is also worth noting that extrusion process can be considered environmentally friendly due to cost reduction, mainly with the treatment of the generated residues (CHEN et al., 2014), in relation to the chemical treatments of modification of dietary fiber. 
Influence of physical methods on the physicochemical properties of dietary fiber

As mentioned, the reduction of dietary fiber particle size to a micro scale improves its physicochemical properties (CHAU et al., 2007), such as water-holding, swelling, oil-binding and cation-exchange capacities (Table 1).

CHAU et al. (2007) evaluated different methods of micronization (ball milling, jet milling and high pressure micronizer) to reduce the particle size of insoluble fiber from carrot. The authors reported that the influence on the functional properties of raw material is greater when the particle size is smaller. These results represented an increase in waterholding, oil-binding and cation-exchange capacities. Increasing in water-holding capacity is due to increase in the number of water-binding sites (WANG et al., 2009) with consequent increase in solubility caused by the diffusion of the water-soluble molecules (ZHAO et al., 2015). During micronization, there is a change in the porosity of fibrous matrix, with an increase in the surface area, causing a redistribution of insoluble components to soluble ones, through the solubilization of protein and pectic substances.

A similar result was reported by DU et al. (2014) in the production of ultra-fine powders from hull-less barley. In addition to the physical and chemical characteristics of the micronized products, the antioxidant capacity indicated an increase in DPPH (2,2-diphenyl-1-picryl-hydrazyl) radical capture capacity and in Ferric Reducing Antioxidant Power (FRAP). Main constituents responsible for this increase in antioxidant activity are the phenolic compounds, which are exposed after alteration or destruction of the macromolecular matrix caused by micronization process and, thus, act as inhibitors or free radical scavengers in the body (ZHU et al., 2014a; ZHAO et al., 2015).

In the study with hull-less barley bran, ZHU et al. (2015) related increase in soluble fraction of dietary fiber after ultra-fine milling as a beneficial factor. This portion helps to decrease blood cholesterol levels as well as control blood glucose levels. The reason for these benefits is the ability of soluble

Table 1 - Effect of micronization on the physicochemical properties and dietary fiber content of different food matrices.

\begin{tabular}{|c|c|c|c|c|c|c|c|}
\hline Food matrix & Treatment & WHC (g water/g) & OBC (g oil/g) & $\mathrm{TDF}^{*}$ & IDF $^{*}$ & $\mathrm{SDF}^{*}$ & Reference \\
\hline \multirow{4}{*}{ Carrot IDF } & Control $(123 \mu \mathrm{m})$ & 12.5 & 1.92 & - & - & - & \multirow{4}{*}{ CHAU et al., 2007} \\
\hline & $\begin{array}{l}\text { Ball milling } \\
(12.4 \mu \mathrm{m})\end{array}$ & 13.00 & 1.99 & - & - & - & \\
\hline & $\begin{array}{l}\text { Jet milling } \\
(28.3 \mu \mathrm{m})\end{array}$ & 12.6 & 3.22 & - & - & - & \\
\hline & $\begin{array}{l}\text { High-pressure } \\
\text { micronization } \\
(7.23 \mu \mathrm{m})\end{array}$ & 42.5 & 56 & - & - & - & \\
\hline \multirow{2}{*}{ Hull-less barley } & $\begin{array}{l}\text { Regular grinding } \\
\quad(172.49 \mu \mathrm{m})\end{array}$ & 4.42 & 0.96 & 13.55 & 9.76 & 3.79 & \multirow{2}{*}{ DU et al., 2014} \\
\hline & $\begin{array}{l}\text { Ultra-fine grinding } \\
\qquad(11.74 \mu \mathrm{m})\end{array}$ & 3.19 & 4.83 & 14.27 & 7.64 & 6.63 & \\
\hline \multirow{2}{*}{ Grape pomace } & $\begin{array}{l}\text { Regular grinding } \\
\quad(73.29 \mu \mathrm{m})\end{array}$ & 1.23 & 0.97 & 86.17 & 68.00 & 17.27 & \multirow{2}{*}{ ZHU et al., 2014b } \\
\hline & $\begin{array}{l}\text { Ultra-fine grinding } \\
\quad(7.06 \mu \mathrm{m})\end{array}$ & 2.20 & 1.43 & 82.47 & 55.97 & 26.50 & \\
\hline \multirow{2}{*}{ Buckwheat hulls } & $\begin{array}{l}\text { Regular grinding } \\
\quad(222.41 \mu \mathrm{m})\end{array}$ & 1.23 & 1.00 & 86.83 & 70.27 & 16.00 & \multirow{2}{*}{ ZHU et al., 2014a } \\
\hline & $\begin{array}{l}\text { Ultra-fine grinding } \\
\quad(12.5 \mu \mathrm{m})\end{array}$ & 2.16 & 1.43 & 83.23 & 56.63 & 26.60 & \\
\hline \multirow{2}{*}{ Hull-less barley bran } & $\begin{array}{l}\text { Regular grinding } \\
\quad(74.31 \mu \mathrm{m})\end{array}$ & 2.25 & 1.74 & 76.5 & 68.2 & 6.46 & \multirow{2}{*}{ ZHU et al., 2015} \\
\hline & $\begin{array}{l}\text { Ultra-fine grinding } \\
\quad(14.06 \mu \mathrm{m})\end{array}$ & 19.53 & 2.03 & 72.00 & 54.4 & 16.1 & \\
\hline
\end{tabular}

${ }^{*}$ Results are expressed as percentage of dry matter.

$\mathrm{WHC}=$ water-holding capacity. $\mathrm{OBC}=$ oil-binding capacity. $\mathrm{TDF}=$ total dietary fiber. $\mathrm{IDF}=$ insoluble dietary fiber. $\mathrm{SDF}=$ soluble dietary fiber. 
fraction to absorb water and form gel, delaying the emptying of the stomach, which contributes with a weight control.

DRAKOS et al. (2017) used jet mill to produce ultra-fine powders from barley and rye flours and observed an increase of damaged starch with the ultra-fine milling process, which increased the water-holding capacity of the powders. This occurs due to greater water absorption and the interactions between the starchy and non-starchy components (proteins and fiber matrix). In the same study, authors pointed out that the decrease of particle size produces a decrease in the content of phenolic compounds, due to the formation of aggregates during milling. What is expected, as observed by HU et al. (2012), is an increase in this amount, with consequent increase in antioxidant activity.

In general, micronization method causes a structural reorganization and the structural changes from ordinate to disordered (amorphous) by breaking intermolecular bonds, obtaining smaller fractions after milling, causing changes in the original structure and; consequently, changes in physicochemical properties (ZHAO et al., 2015). The components of dietary fiber are redistributed mainly by the breakdown/degradation of hemicellulose, cellulose and lignin, which are converted into lower molecular compounds (ZHU et al., 2014b).

Using extrusion as a method to improve the functional properties of dietary fiber, attention should be paid to the temperature being used in the process (Table 2). JING \& CHI (2013), while evaluating the effect of different extrusion conditions on the soluble fiber content of soybean residue, reported that the maximum temperature to be used for extrusion of this raw material is $110^{\circ} \mathrm{C}$; above this temperature, a decrease of the soluble fiber content occurs due to the depolymerization of the glycosidic bonds of the polysaccharides induced by the increase in temperature. In the same study, the authors obtained increased dietary fiber solubility (hydration capacity), as well as levels of soluble fiber and waterholding, and oil-binding capacity. High temperature used in the extrusion process modifies the structural characteristics of fiber, facilitating absorption of water and oil.

YAN et al. (2015) did not observe a significant difference for protein, lipid, ash and starch contents between non-extruded and extruded wheat bran samples. As well as HUANG \& MA (2016) for the extruded orange pomace, these authors stated that heating during the extrusion process modifies the texture of the food material by breaking the structure of dietary fiber components of the vegetables, increasing levels of xylose, mannose, glucose and uronic acid. The extrusion process retains the water inside the fibrous matrix, so there is an increased water-holding capacity, while oil-binding capacity is related to the polysaccharide structure of the fiber and is influenced by the surface properties, charge density and the hydrophilic nature of the fiber particles (HUANG \& MA, 2016).

Less pronounced increases in soluble fiber content were observed by HONCU et al. (2016) when evaluating changes in barley dietary fiber components during the extrusion process. This fact is due to dietary fiber content being dependent on the composition of the material being extruded and process parameters. By means of microscopy, the structure of the extruded material was shown

Table 2 - Effect of extrusion processing on the physicochemical properties and dietary fiber content of different food matrices.

\begin{tabular}{|c|c|c|c|c|c|c|c|}
\hline Food matrix & Treatment & WHC (g water/g) & OBC (g oil/g) & $\mathrm{TDF}^{*}$ & $\mathrm{IDF}^{*}$ & $\mathrm{SDF}^{*}$ & Reference \\
\hline \multirow{2}{*}{ Soybean residue } & Not extruded & 7.99 & 77.42 & 63.03 & 60.82 & 2.05 & \multirow{2}{*}{ JING \& CHI, 2013} \\
\hline & Extruded & 10.51 & 97.08 & 63.09 & 50.39 & 12.65 & \\
\hline \multirow{2}{*}{ Wheat bran } & Not extruded & - & - & 43.20 & 33.38 & 9.82 & \multirow{2}{*}{ YAN et al., 2015} \\
\hline & Extruded & - & - & 44.16 & 27.04 & 16.76 & \\
\hline \multirow{2}{*}{ Orange pomace } & Not extruded & 5.80 & 1.23 & 63.83 & 46.52 & 17.3 & \multirow{2}{*}{ HUANG \& MA, 2016} \\
\hline & Extruded & 6.73 & 0.84 & 63.36 & 30.29 & 33.57 & \\
\hline \multirow[b]{2}{*}{ Barley } & Not extruded & - & - & 18.14 & 10.00 & 6.80 & \multirow[b]{2}{*}{ HONCU et al., 2016} \\
\hline & Extruded & - & - & 16.71 & 8.78 & 8.17 & \\
\hline
\end{tabular}

*Results are expressed as percentage of dry matter.

$\mathrm{WHC}=$ water-holding capacity. $\mathrm{OBC}=$ oil-binding capacity. $\mathrm{TDF}=$ total dietary fiber. $\mathrm{IDF}=$ insoluble dietary fiber. $\mathrm{SDF}=$ soluble dietary fiber. 
to be compact, with partially gelatinized starch, partially denatured protein and rearrangement of dietary fiber components. In addition, the increase in soluble fiber is due to the transglycosylation in which the 1,4 bonds between carbon and oxygen are cleaved and new anhydroglucose bonds are formed. Decrease in insoluble fiber levels may be due to the degradation of insoluble polysaccharides, cellulose and hemicellulose, into simple sugars (ELLEUCH et al., 2011).

One way of ascertaining the efficiency of in vitro test results is by in vivo analysis. CHEN et al. (2014) evaluated the effect of extrusion on the soluble fiber content from soybean residue in a mice fat- and cholesterol-rich diet. Initially, there was an increase in the content of soluble fiber in the extruded material compared to the non-extruded one. Regarding the in vivo assay, the incorporation of extruded dietary fiber into the diet decreased the concentration of physiological markers associated with cardiovascular risk, such as total cholesterol, low density lipoprotein and triglycerides and increased in the high density lipoprotein concentration. The authors reported that these effects may be due to the presence of carboxymethyl cellulose, which imprisons the cholesterol crystals, due to their well and pore morphology, forming a gel in the small intestine, which positively contribute to bind the crystals of excess cholesterol and facilitate excretion of the organism.

\section{CONCLUSION}

Micronization and extrusion processes can be used to improve functional properties of dietary fiber, since both change its physicochemical properties, such as water-holding capacity, oilbinding, and cation-exchange capacities, associated with the beneficial effects of consumption of dietary fiber in the body. Research should be carried out in order to understand the role of improving the functional properties of dietary fiber in relation to the products in which they are incorporated. As well as the effect of these processes on improving the functional properties of dietary fiber in vivo must be investigated. Thus, it is possible to verify the improvement on the functional properties of dietary fiber in different food matrices.

\section{ACKNOWLEDGEMENTS}

This study was financed in part by the Coordenação de Aperfeiçoamento de Pessoal de Nível Superior - Brasil (CAPES) - Finance Code 001

\section{DECLARATION OF CONFLICT OF INTERESTS}

The authors declare no conflict of interest. The founding sponsors had no role in the design of the study; in the collection, analyses, or interpretation of data; in the writing of the manuscript, and in the decision to publish the results.

\section{AUTHORS' CONTRIBUTIONS}

The authors contributed equally to the manuscript.

\section{REFERENCES}

ABDUL-HAMID, A.; LUAN, Y.S. Functional properties of dietary fibre prepared from defatted rice bran. Food Chemistry, v.68, p.15-19, 2000. Available from: <https://www.sciencedirect. com/science/article/pii/S0308814699001454>. Accessed: Mar. 20, 2017. doi: 10.1016/S0308-8146(99)00145-4.

AKDOGAN, H. Rheological properties of rice starch at high moisture contents during twin-screw extrusion. LWT- Food Science and Technology, v.30, p.488-496, 1997. Available from: <https://www.sciencedirect.com/science/article/pii/ S0023643896902157>. Accessed: Nov. 16, 2016. doi: 10.1006/ fstl.1996.0215.

AMERICAN ASSOCIATION OF CEREAL CHEMISTS (AACC). The definition of dietary fiber. v.46, p.112-126, 2001. Available from: <http://www.scisoc.org/aacc/DietaryFiber/ report.html>. Accessed: Nov. 16, 2016.

ASCHERI, D.P.R. et al. Efeito da extrusão sobre a adsorção de água de farinhas mistas pré-gelatinizadas de arroz e bagaço de jabuticaba. Ciência e Tecnologia de Alimentos, v.26, n.2, p.325-335, 2006. Available from: < http://www.scielo.br/scielo.php?script=sci_artte xt\&pid=S0101-20612006000200015>. Accessed: Mar. 05, 2017. doi: $10.1590 / \mathrm{S} 0101-20612006000200015$.

CHALERMCHAIWAT, P. et al. Antioxidant activity, free gamma-aminobutyric acid content, selected physical properties and consumer acceptance of germinated brown rice extrudates as affected by extrusion process. LWT - Food Science and Technology, v.64, p.490-496, 2015. Available from: <https:// www.sciencedirect.com/science/article/pii/S0023643815003485>. Accessed: Nov. 18, 2017. doi: 10.1016/j.lwt.2015.04.066.

CHAU, C. F. et al. Different micronization methods significantly improve the functionality of carrot insoluble fibre. Food Chemistry, v.100, p.1402-1408, 2007. Available from: <https://www.sciencedirect.com/science/ article/pii/S0308814605010757>. Accessed: Apr. 14, 2016. doi: 10.1016/j.foodchem.2005.11.034.

CHEN, Y. et al. Novel blasting extrusion processing improved the physicochemical properties of soluble dietary fiber from soybean residue and in vivo evaluation. Journal of Food Engineering, v.120, p.1-8, 2014. Available from: <https://www.sciencedirect. com/science/article/pii/S0260877413003683>. Accessed: Mar. 20, 2017. doi: 10.1016/j.jfoodeng.2013.07.011.

DAOU, C.; ZHANG, H. Study on functional properties of physically modified dietary fibres derived from defatted rice bran. Journal of Agricultural Science, v.4, n.9, p.85-97, 2012. 
Available from: $<$ http://www.ccsenet.org/journal/index.php/jas/ article/view/16878>. Accessed: May,. 12, 2016. doi: 10.5539/ jas.v4n9p85.

DENG, Q. et al. Chemical composition of dietary fiber and polyphenols of five different varieties of wine grape pomace skins. Food Research International, v.44, p.2712-2720, 2011. Available from: <https://www.sciencedirect.com/science/ article/pii/S0963996911003425>. Accessed: Mar. 20, 2017. doi: 10.1016/j.foodres.2011.05.026.

DRAKOS, A. et al. Influence of jet milling and particle size on the composition, physicochemical and mechanical properties of barley and rye flours. Food Chemistry, v.215, p.326332, 2017. Available from: <https://www.ncbi.nlm.nih.gov/ pubmed/27542482>. Accessed: Jan. 24, 2018. doi: 10.1016/j. foodchem.2016.07.169.

DU, B. et al. Physicochemical and antioxidant properties of dietary fibers from Qingke (hull-less barley) flour as affected by ultrafine grinding. Bioactive Carbohydrates and Dietary Fibre, v.4, p.170-175, 2014. Available from: <https://www.sciencedirect. com/science/article/pii/S2212619814000473>. Accessed: Mar. 20, 2017. doi: 10.1016/j.bcdf.2014.09.003.

ELLEUCH, M. et al. Dietary fibre and fibre-rich by-products of food processing: Characterisation, technological functionality and commercial applications: A review. Food Chemistry, v.124, p.411-421, 2011. Available from: <https://www.sciencedirect. com/science/article/pii/S0308814610007880>. Accessed: Dec. 02, 2016. doi: $10.1016 /$ j.foodchem.2010.06.077.

GRIGELMO-MIGUEL, N. et al. Characterisation of peach dietary fibre concentrate as a food ingredient. Food Chemistry, v.65, p.175-181, 1999. Available from: <https://www.sciencedirect. com/science/article/pii/S0308814698001903>. Accessed: Dec. 02, 2016. doi: 10.1016/S0308-8146(98)00190-3.

GUILLON, F.; CHAMP, M. Structural and physical properties of dietary fibres, and consequences of processing on human physiology. Food Research International, v.33 p.233-245, 2000. Available from: <https://www.sciencedirect.com/science/article/ pii/S0963996900000387>. Accessed: Mar. 02, 2016. doi: 10.1016/ S0963-9969(00)00038-7.

HONCU, I. et al. The effects of extrusion on the content and properties of dietary fibre components in various barley cultivars. Journal of Cereal Science, v.68, p.132-139, 2016. Available from: <https://www.sciencedirect.com/science/ article/pii/S0733521016300121>. Accessed: Mar. 20, 2017. doi: $10.1016 /$ j.jcs.2016.01.012.

HU, J. et al. Effect of superfine grinding on quality and antioxidant property of fine green tea powders. LWT - Food Science and Technology, v.45, p.8-12, 2012. Available from: <https://www. sciencedirect.com/science/article/pii/S0023643811002611>. Accessed: Nov. 16, 2017. doi: 10.1016/j.lwt.2011.08.002.

HUANG, Y. L.; MA, Y. S. The effect of extrusion processing on the physicochemical properties of extruded orange pomace. Food Chemistry, v.196, p.363-369, 2016. Available from: $<$ https:// www.ncbi.nlm.nih.gov/pubmed/26304360>. Accessed: Mar. 20, 2018. doi: 10.1016/j.foodchem.2015.07.039.

JING, Y.; CHI, Y. J. Effects of twin-screw extrusion on soluble dietary fibre and physicochemical properties of soybean residues.
Food Chemistry, v.138, p.884-889, 2013. Available from: <https:// www.sciencedirect.com/science/article/pii/S0308814612018754>. Accessed: Jan. 24, 2017. doi: 10.1016/j.foodchem.2012.12.003.

KENDALL, C. W. C. et al. The link between dietary fiber and human health. Food Hydrocolloids, v.24, p.42-48, 2010. Available from: <https://www.sciencedirect.com/science/article/ pii/S0268005X09001611>. Accessed: Mar. 20, 2018. doi: 10.1016/j.foodhyd.2009.08.002

LEVYA-CORRAL, J. et al. Polyphenolic compound stability and antioxidant capacity of apple pomace in an extruded cereal. LWT- Food Science and Technology, v.65, p.228-236, 2016. Available from: $<$ https:// www.sciencedirect.com/science/article/pii/S0023643815300906>. Accessed: Mar. 20, 2017. doi: 10.1016/j.lwt.2015.07.073.

MORALES, P. Lentil flour formulations to develop new snack-type products by extrusion processing: Phytochemicals and antioxidant capacity. Journal of Functional Foods, v.19, p.537-544, 2015. Available from: <https://www.sciencedirect.com/science/article/ pii/S1756464615004612>. Accessed: Jan. 24, 2017. doi: 10.1016/j. jff.2015.09.044.

MUDGIL, D; BARAK, S. Composition, properties and health benefits of indigestible carbohydrate polymers as dietary fiber: A review. International Journal of Biological Macromolecules, v.61, p.1-6, 2013. Available from: <https://www.ncbi.nlm.nih. gov/pubmed/23831534>. Accessed: Mar. 20, 2017. doi: 10.1016/j. ijbiomac.2013.06.044.

SOUZA, R. C. R.; ANDRADE, C. T. Investigação dos processos de gelatinização e extrusão do amido de milho. Polímeros: ciência e tecnologia, v.10, n.1, p.24-30, 2000. Available from: $<$ http://www.scielo.br/scielo.php?script=sci_arttext\&pid $=$ S0104-14282000000100006 $>$. Accessed: Dec. 02, 2016. doi: 10.1590/S0104-14282000000100006.

VITAGLIONE, A. et al. Cereal dietary fibre: a natural functional ingredient to deliver phenolic compounds into the gut. Trends in Food Science \& Technology, v.19, p.451- 463, 2008. Available from: $<\mathrm{https} / /$ www.sciencedirect.com/science/ article/pii/S0924224408000447>. Accessed: Dec. 02, 2016. doi: $10.1016 /$ j.tifs.2008.02.005

WANG, C. C. R. et al. Effect of micronization on functional properties of the water caltrop (Trapa taiwanensis Nakai) pericarp. Food Chemistry, v.113, p.970-974, 2009. Available from: <https:// www.sciencedirect.com/science/article/pii/S0308814608010066>. Accessed: Dec. 02, 2016. doi: 10.1016/j.foodchem.2008.08.048.

YAN, X. et al. Blasting extrusion processing: The increase of soluble dietary fiber content and extraction of soluble-fiber polyssacharides from wheat bran. Food Chemistry, v.180, p.106115 , 2015. Available from: <https://www.sciencedirect.com/ science/article/pii/S030881461500151X >. Accessed: Mar. 20, 2017. doi: 10.1016/j.foodchem.2015.01.127.

ZHAO, X. et al. Effect of superfine grinding on the physicochemical properties and antioxidant activity of red grape pomace powders. Powder Technology, v.286, p.838-844, 2015. Available from: <https://www.sciencedirect.com/science/ article/pii/S0032591015300735>. Accessed: Mar. 05, 2017. doi: 10.1016/j.powtec.2015.09.025.

ZHU, F. et al. Effect of micronization technology on physicochemical and antioxidant properties of dietary fiber from 
buckwheat hulls. Biocatalysis and Agricultural Biotechnology, v.3, p.30-34, 2014a. Available from: <https://www.sciencedirect. com/science/article/pii/S1878818113001552>. Accessed: Nov. 18, 2017. doi: 10.1016/j.bcab.2013.12.009.

ZHU, F. M. et al. Effect of ultrafine grinding on physicochemical and antioxidant properties of dietary fiber from wine grape pomace. Food Science and Technology International, v.20, p.55-62, 2014b. Available from: <https://www.ncbi.nlm. nih.gov/pubmed/23733819>. Accessed: Nov. 18, 2017. doi: $10.1177 / 1082013212469619$.

ZHU, F. et al. Superfine grinding improves functional properties and antioxidant capacities of bran dietary fibre from Qingke (hullless barley) grown in Qinghai-Tibet Plateau, China. Journal of Cereal Science, v.65, p.43-47, 2015. Available from: <https:// www.sciencedirect.com/science/article/pii/S0733521015300187>. Accessed: Mar. 20, 2017. doi: 10.1016/j.jcs.2015.06.006 